NBER WORKING PAPER SERIES

\title{
PROPERTY AND CASUALTY SOLVENCY \\ FUNDS AS A TAX AND SOCIAL \\ INSURANCE SYSTEM
}

James Bohn

Brian J. Hall

Working Paper No. 5206

\section{NATIONAL BUREAU OF ECONOMIC RESEARCH \\ 1050 Massachusetts Avenue \\ Cambridge, MA 02138 \\ August 1995}

This paper is part of the NBER's project on Property and Casualty Insurance. We thank John Campbell, Richard Caves, Martin Feldstein, Paul Gulko, Louis Kaplow, Deborah Lucas and Sean Mooney for helpful comments and the NCIGF for providing much of the data. This paper is part of NBER's research program in Public Economics. Any opinions expressed are those of the authors and not those of the National Bureau of Economic Research.

(C) 1995 by James Bohn and Brian J. Hall. All rights reserved. Short sections of text, not to exceed two paragraphs, may be quoted without explicit permission provided that full credit, including $(\odot)$ notice, is given to the source. 


\title{
PROPERTY AND CASUALTY SOLVENCY \\ FUNDS AS A TAX AND SOCIAL \\ INSURANCE SYSTEM
}

\begin{abstract}
When a Property and Casualty (P\&C) insurance company becomes insolvent, solvent
\end{abstract} insurance companies are forced to pay assessments (a form of taxation) to state guarantee funds ("solvency funds") in order to protect the policyholders of the failed companies. We produce estimates of the costs to the guarantee funds of resolving P\&C insurance company insolvencies. We find that the total net costs (payments by the fund less recoveries by the fund) of resolving insolvencies are remarkably high. We estimate that the mean ratio of net costs to assets is approximately one, implying that insolvent companies have liabilities that are roughly twice as large as assets when they fail. Our cost estimate for resolving insurance company insolvencies is roughly three times higher than similar estimates for banks. We also find that the ratio of net costs to assets tends to be higher for small firms, poorly capitalized firms, firms writing significant premiums in long tail lines, and firms that fail because of disasters. Our findings also indicate that the resolution of insolvencies is typically quick. More than 60 percent of all costs to the fund for a given insolvency occur within two years, and more than three-quarters of total costs occur within three years. However, we find that firms with a high proportion of premiums in long tail lines take much longer to resolve.

James Bohn

Department of Economics

Harvard University

Cambridge, MA 02138
Brian J. Hall

Department of Economics Harvard University

Cambridge, MA 02138 


\section{Introduction}

In the event of a Property and Casualty (P\&C) insurance company failure, the losses suffered by the insured are protected by state guarantee funds (or solvency funds). Guarantee funds pay the claims of policyholders of the failed firm, making up any shortfall between the failed firms' assets and the cost of these claims by levying assessments on the premiums collected by solvent insurers in that state. In recent years state guarantee funds have come under increasing pressure as more P\&C insurance companies failed. As shown in Figure 1, both the number of insolvencies and the costs to state guarantee funds have increased sharply since the mid-1980s. In 1993, the net costs to state guarantee funds was a record high of $\$ 800$ million.

Some have argued that the dramatic increase in the number of insolvencies in the mid1980s was caused by price cutting by liability insurers during the early 1980 's (U.S. House of Representatives, 1990). In addition, some observers have noted a marked increase in the expected value and variance of claim cost distributions at this time (Clarke et. al 1988). Regardless of the reason for the wave of insolvencies, P\&C insurance companies and policymakers have been concerned about the rising level of the assessments, and the potential for much higher assessments should there be an even larger wave of insolvencies.

These facts raise a series of important issues about the solvency fund system, many of which have not been addressed in the academic literature. First, to what extent does the solvency fund system create perverse incentives? Because healthy firms are required to make (indirect) payments to the claimants of insolvent firms, the P\&C solvency fund system is like a tax and social insurance system. The mandatory nature of the assessments means that they can 
viewed as a tax on healthy firms. The assessments (taxes), which are not risk-rated, are the price that companies are forced to pay in order to purchase second-level insurance against the possibility of failure and the inability to pay claims.

In addition to any distortions created by mandatory assessments/taxes, this social insurance scheme may create substantial moral hazard problems. This is particularly true for insurance companies that are insolvent or near insolvent. Such companies have the same incentive problems ("heads I win tails somebody else loses") that were faced by the S\&Ls. Cash-poor and near-bankrupt P\&C companies have the incentive to undercut competitor's prices in order to write lots of (potentially risky) policies, just as S\&Ls had the incentive to offer attractive deposit rates in order to increase deposits and make risky loans. Note that this moral hazard problem would be mitigated or even eliminated if $\mathrm{P} \& \mathrm{C}$ companies paid assessments that were related to their riskiness. The difficulty, of course, is determining how to measure their riskiness.

A second important issue concerns the exposure of the solvency fund system. That is, how "exposed" are state guarantee funds to various shocks (disasters etc.) that cause insolvencies? What scenarios would cause the solvency fund assessments to reach their maximum level (typically one or two percent of premiums per year)? How exposed is the system to a very large shock or set of shocks that would create an S\&L-like problem in the P\&C insurance industry?

The first step toward answering any of these questions is to understand the magnitude, nature and the determinants of the costs of resolving P\&C insolvencies. The adequacy of guarantee funds depends on both the number of insolvencies and the net costs to the fund per 
insolvency. For the most part, previous studies of insolvencies in the P\&C industry have involved estimating hazard models to predict the number/likelihood of insolvency. In contrast, we focus on the cost dimension of $\mathrm{P} \& \mathrm{C}$ company insolvencies.

We have several major goals in this study. First, we estimate the total net costs of resolving insurance company insolvencies. While a number of studies have estimated insolvency costs for the banking industry, there have been no studies that have produced such an estimate for insurance companies. Second, since resolution of a given insolvency typically takes many years, we estimate the typical time path of the guarantee payments (and net costs) and analyze how these time paths differ with the composition of the firm's book of business. Third, we examine the determinants of the size of losses associated with insurance company insolvencies.

The results of our analysis should be of practical importance to regulators who seek to design prudent safeguards against insurance company failures. More informed regulation should result from a better understanding of the magnitude and determinants of the costs of resolving insurance company failures. Research in this area is particularly needed in light of the current interest in restructuring the guarantee fund system. ${ }^{1}$

This paper proceeds as follows. The next section discusses the organization and administration of the guarantee fund system. In the third section, we describe the data and

1 There have been a number of recent proposals to reform the guarantee system. In 1992, the NAIC's Focus Group issued a report calling for a uniform national receivership system. Alternative proposals include Hall and Hall's (1993) proposal to develop an insurer-nun guarantee system and Schacht and Gallanis (1993) modification of the current system to facilitate greater interstate cooperation. There is also ongoing interest in designing a system of risk-based assessments on premiums (see Cummins, 1988). Risk-based capital guidelines have recently been adopted in some states. 
produce estimates of the time-path of resolution costs. In the fourth section, we use these time paths to produce estimates of the costs to the solvency funds of an "average" insolvency. In the fifth section, we regress insolvency costs on various firm characteristics to examine the determinants of insolvency costs. We discuss potential reasons for our finding that insolvency costs are quite high in the sixth section. The seventh section concludes.

\section{The Guarantee Fund System: Background}

In this section, we provide background information on the organization and administration of the guarantee fund system. ${ }^{2}$ The current guarantee fund system was a response to a federal initiative in the late 1960 's to establish a guarantee system for insurance companies similar to the FDIC. As a result of the threat of federal intrusion into an industry heretofore regulated by the states, the National Association of Insurance Commissioners (NAIC) proposed model legislation for the establishment of guarantee funds at the state level. By 1971, 35 states had adopted guarantee fund provisions based on the NAIC's Model Act, and by 1982 , every state had adopted some form of guarantee fund legislation. In most cases, the organization of the fund closely resembles that outlined in the Model Act.

The Model Act calls for the formation of a not-for-profit association consisting of all companies licensed to write insurance within a state in lines covered by the guarantee fund. Membership in the association is compulsory. This association is a distinct entity from the state insurance department. The association is governed by a board composed of

2 Much of the discussion in the section is drawn from Epton and Bixby (1976), Duncan (1984) and NCIGF (1993b). 
representatives of member firms and the state insurance commissioners office. When a company becomes insolvent, the guarantee fund services and pays the claims of policyholders of the failed insurer in the same way that it would be provided by a solvent insurance company. Each state's guarantee fund pays only for the claims of the insured residing in that state. Thus, the failure of a multi-state insurer triggers action on the part of several guarantee associations.

Guarantee funds typically pay the full amount of an insured's claims up to a certain cap, except for a small deductible. ${ }^{3}$ Any shortfall between the assets of the failed insurer and the obligations of the fund is covered by levying assessments against healthy firms doing business in the state of the insolvent firms. Assessments of member firms are directly proportional to their share of direct premiums written within a state in lines covered by the fund. ${ }^{4}$ Thus, assessments are not based on any measure of risk. Assessments are also made to cover the administrative, legal and other expenses associated with the operation of the state guarantee funds. Thus, the total costs of resolving insolvencies include the administrative costs of managing the guarantee funds.

In 49 states, funds operate on a post-assessment basis. The funds maintain no reserves

3 The cap on the funds liability per claim are typically $\$ 300,000$ to $\$ 500,000$. Some states maintain caps as low as $\$ 100,000$. As a practical consideration, the upper limits are high enough that they are rarely binding in the claims administration process. Deductibles range from 0 to $\$ 200$. However, most funds bave deductible of $\$ 100$.

4 Guarantee funds are typically organized into separate accounts covering broad lines of insurance. The most common form of organization has three separate accounts -. workmen's compensation, automobile and "all other" types of insurance. However, different states operate as few as one or as many as six accounts. 
and only assess member insurers after an insolvency occurs. ${ }^{5}$ Assessments are typically capped at 2 percent of premiums written, although some states maintain lower caps. All states have some provision that enables companies to partially offset amounts assessed by the fund. In most states, insurers are allowed to include the cost of assessments as a factor in determining premiums. Some states allow insurers to recover a portion of their assessment with credits against their premium tax liability, which shifts a portion of the costs of the insolvency to the state.

Guarantee funds are not responsible for the detection or prevention of insurer insolvencies. The typical sequence of events in an insurance insolvency begins with the filing of a petition in state court by the insurance commissioner in the company's state of domicile. If the court finds the insurer to be insolvent, the insurance regulators take over the management of the firm. In most cases, regulators begin to liquidate the assets of the failed insurer and turn the file containing the claims over to the managers of the guarantee fund. The guarantee fund pays the claims of the insureds from the assessments levied on healthy insurers and the proceeds of the sale of the assets of the failed insurer. Since policyholders cannot be paid by the guarantee fund before an order of liquidation has been approved by the court, regulators typically file a petition to liquidate the firm soon after the comapny has been found to be insolvent. Action by the guarantee fund is terminated once all claims against the estate of the failed insurer have been paid. This may take over a decade if the failed firm was

5 The exception is New York State, which adopted guarantee fund legislation in 1947. Unlike other funds, Now York's operates on a pre-assessment basis. The state maintains a fund of $\$ 150$ to $\$ 200$ million for the resolution of insurance faihures. Firms writing insurance in the state are assessed whenever the fund balance falls below the lower bound. 
involved in liability or compensation insurance. ${ }^{6}$

\section{The Time-Path of Resolution Costs}

In the next section, we use data obtained from the NCIGF to estimate the net costs to the guarantee funds per insolvency. However, because the amount of time it takes to resolve an insolvency is typically long, we first estimate the typical time-paths of these costs and analyze how these time-paths differ with the composition of the failed insurer's business. Although our time-path estimates may be of independent interest to regulators, our main reason for analyzing the time paths is because it is a necessary first step (as will be explained later) to estimating total costs per insolvency.

Guarantee payments are the sum of all expenditures by the guarantee fund including legal costs, operating expenses, and paid claims to those who were insured by the insolvent company. It should be emphasized that these payments are costs to the fund over and above the proceeds from liquidation of the assets of the insolvent companies. On occasion, the fund receives cash inflows, called recoveries, from the (typically late) liquidation of the assets of the failed company. Net costs to the fund are the difference between fund payments and recoveries.

\subsection{Data Description}

Our initial list of insolvencies was obtained from the 1992 and 1993 editions of the

\footnotetext{
6 Alternatively, the regulator may take actions to restore the financial health of the insolvent insurer. These rehabilitations are quite rare. Failures have been successfully resolved by rehabilitation in about dozen cases (NCIGF, 1993a)
} 
NCIGF's Assessment and Financial Information Report (1993a), which provides annual and cumulative payments, recoveries, and net cost data for all insolvencies that necessitated guarantee fund payments. Their 1993 report provided this data for 356 firms. Action on the part of guarantee funds is triggered by an order to liquidate the failed insurer. We searched Best's Insurance Reports, Best's Solvency Report and documents provided by the NCIGF to determine the liquidation date and the date that each insurer became insolvent. We were able to determine the date of liquidation of 328 ( 92 percent) of these firms. The 28 firms for which liquidation dates were unavailable were very small. Collectively, they accounted for less than 1 percent of total fund payments. Data on annual fund payments and net costs (payments minus recoveries) for each firm were obtained from the 1992 and 1993 issues of the NCIGF's annual report. Due to differences in reporting practices, comparable annual data at the firm level were not available prior to 1992.

Financial data for each firm was obtained from the National Association of Insurance Commissioners (NAIC) Annual Statement Database. Financial data on the firm was drawn from the annual statement filed by the firm in the year before the firm became insolvent. We omit firms that are inactive or in run off by excluding firms with direct premium writings less than or equal to zero. A firm was also excluded from our sample if we could not determine the year in which the firm became insolvent. Because machine readable financial statement data is not available prior to 1984, we confined our analysis to the set of firms that were liquidated in the period between 1986 and 1993. Of the 214 liquidations involving fund activity in that period, we were able to obtain complete financial information on 141 firms ( 66 percent of the total). Firms included in the sample accounted for $80 \%$ of fund payments. We made an adjustment for inflation using the CPI 
so that all financial statement information and fund activity data are in real 1993 dollars. Since New York is the lone pre-assessment solvency fund and is not included in the NCIGF data, we do not include New York in our sample. For firms that operate in multiple states that include New York, we scaled the size (measured by assets) of these firms down by the percentage of premiums written in New York ${ }^{7}$. Our results are not sensitive to our scaling procedure.

\subsection{The Time Path of Payments and Costs}

Because of typically long resolution times, the majority of $\mathrm{P} \& \mathrm{C}$ insolvencies were not fully resolved as of 1993. Our approach therefore is to estimate "typical" paths of costs, and then use these paths, along with the data that we do have on to-date cumulative costs, to determine the total costs for each (typically unresolved) insolvency. We used the annual payment and cost data from 1992 and 1993 so that each insolvency produced two observations in our dataset. Time period $t=1$ is defined as the year the liquidation order was issued. For example, if a firm was liquidated in 1989, the 1993 payments and net costs would form an observation in the year $=5$ cohort while the 1992 results would be an observation in the year $=4$ cohort. We begin with the year of liquidation because guarantee funds typically do not make payments to claimants until an order of liquidation has been obtained.

${ }^{7}$ There was one firm that operated entirely within New York state in the year prior to insolvency. However, it had written a small amount of business outside of New York in previous years and thus it's failure prompted a small amount of fund payments. We dropped this firm from our sample. The percentage of premiums written in Ney York State averaged only two percent in the remaining companies. 
We estimated the following equation, which will be referred to as specification 1 :

$$
\text { Payments }_{t s} \cdot \beta_{t} \cdot \text { Premiums }_{t_{4}}+\epsilon_{i t}
$$

for each of the eight cohorts $(t=1, \ldots, 8)$. Payments $s_{i t}$ are the payments by the guarantee funds to the policyholders of firm $i$ in year $t$ and premiums $s_{i 0}$ are the direct premiums written by firm $i$ in the year prior to insolvency, $\mathrm{t}_{0}$. Thus, eight separate regressions were run.

We start with payments as the regressor rather than net costs because recoveries occur in large lump sums and net costs may therefore be more prone to outliers. ${ }^{8}$ As will be shown later, however, the paths using payments and net costs are qualitatively similar (and net costs are always lower since recoveries are subtracted), although as expected the estimated paths of net costs are slightly less smooth.

In Table 1, we report the results of this regression. The specification has a nice interpretation. Each coefficient indicates the amount of payments in year $t$ that are associated with another dollar of premiums written in the year prior to insolvency $\left(\mathrm{t}_{0}\right)$. We suppress the constant terms since they were typically insignificant and because excluding them allows the coefficients to be more easily interpreted. We estimate the coefficients to year 8 only because of the data limitations suggested earlier.

Note that all of the coefficients are highly significant. They imply that every dollar in total premiums written in the year previous to insolvency is associated with payments to the

\footnotetext{
${ }^{8}$ We reestimated all of the models in this section after trimming outliers from the dataset. Our criteria for determining whether an observation was abnormally influential was based on the ratio of the determinant of the covariance matrix in the full sample to the determinant of the covariance matrix when an observation is deleted from the dataset. This method and the suggested critical values is discussed in Besley, Kuh and Welsch (1980). The deletion of abnormally influential observations did not substantively alter the results.
} 
guarantee funds of about 25 cents in year 1 (the year of liquidation), 27cents in year 2, 14 cents in year 3 and so on to only 4 cents in year 8 . The typical pattern of payments increases slightly between year 1 and year 2 and then falls, fairly smoothly, until it drops to a very small amount in year 8. It also seems clear that the vast majority of payments occur in the first 2 or 3 years following a liquidation.

Note also that the coefficients add to about .89 which implies that each dollar of premiums written is associated with, on average, 89 cents of payments made by the state guarantee funds in the first 8 years alone. ${ }^{9}$ We discuss total payments, and net costs, in the next sub-section.

As a check on the implied time path pattern, we regressed payments in 1993 on payments in 1992 for each liquidation (specification 2). Since firms were liquidated in different years, this enables us to determine the relationship between costs in year $t$ with the costs in year $\mathrm{t}-1$ for various years since liquidation. The results are shown in Table 2 . They point to the same basic pattern. Costs are slightly higher (about 1.25 times higher) in year 2 than in year 1 , but then decline relative to the previous year in each year thereafter.

Both specifications imply a particular pattern of payments over time. The only tricky issue is what to assume about the payments in the years beyond year 8 . Fortunately, the results from the first specification (payments regressed on premiums) suggest that the payments in year $\mathbf{8}$ are relatively small. Barring some unusual pattern beyond year $\mathbf{8}$, it seems likely that the out-year payments are not large. We produce "terminal value costs," which we define as

${ }^{9}$ This number is consistent with the very high estimates of costs to assets that we report in the next section. 
the sum of total costs beyond year 8 , by averaging the "rate of decline" (which is implied in the first specification and explicitly estimated in the second specification) for years 2 through $8^{10}$. We then assume that this rate of decline is constant for all years beyond year 8 and assume that payments increase forever at this declining rate. It turns out that for both specifications 1 and 2, the terminal value costs are small -- 11 and 5 percent of total payments respectively. ${ }^{11}$

Table 3 and Figure 2 show the implicit paths of these payments over time. For each model, and for each year, the percentage of cumulative payments are reported (i.e. the amount of payments made in that year as a fraction of implied total payments to resolve the insolvency). What is striking about the results is the similarity between the paths. In both cases, about one quarter of total payments are made in year 1 , slightly more than half by year 2 , about two-thirds by year 3 and three-quarters by year 4 .

We now turn to estimating the time path of costs. Following our first specification for

${ }^{10}$ The rates of change between year 1 and year 2 are unlikely to tell us much about the rate of decline in the years after the 8th year.

11 Terminal values were calculated under the assumption that payments and net costs would continue to decrease at the same rate experienced in years 2 through 8 . In the first specification we calculated the rate of decrease, $r$, and terminal value as:

$$
I=\left(\beta_{\text {your }} / \beta_{\text {your } 2}\right)^{1 / 6} \quad \text { Terminal Value }-\beta_{\text {yourt }} \cdot \frac{r}{1-r}
$$

Since our estimate of $\beta_{\text {year }}$ is somewhat imprecise, we calculate the rate of decline using the average of $\beta_{\text {yean }}, \beta_{\text {years }}$ and $\beta_{\text {yeary }}$. In the second specification, the rate of decresse was the average of $\beta_{\text {Years }}$ through $\beta_{\text {Yeare }}$ The terminal value was calculated the same way as in specification 1. 
payments, we estimated:

$$
\text { Net Casts }{ }_{t u} \cdot \beta_{t} \cdot \text { Premiums } u_{t} \cdot \epsilon_{t u}
$$

for each of the eight cohorts $(t=1, \ldots, 8)$. The results of these eight regressions are shown in Table 4. The results show the same basic pattern as the payments regression. The coefficient on total premiums is slightly larger in year 2 than year 1 and then decline thereafter. As suggested earlier, the declining pattern is less smooth because in some cases, large lump-sum recoveries from the estate of the failed insurers may be realized late in the liquidation process. This probably accounts for the negative, but insignificant, coefficient in year 6 . For the most part, the other coefficients are statistically significant and sensible; the coefficients on net costs are almost uniformly (slightly smaller) than the coefficients on payments, which makes sense since net costs equal payments minus (always positive) recoveries. Note also that the sum of the coefficients for the eight years are equal to .75 , which implies that each dollar of premiums written in the year before insolvency is associated with costs to the guarantee fund of 75 cents in the first eight years. The equivalent figure for payments was 89 cents.

Using the same procedure as before, we construct the time path for net costs. This time path is shown in Table 5 and Figure 3, with the payment path also shown for comparison. The time path of payments and net costs is similar, the only difference being that an even larger fraction of total costs occur in the first few years. For example, by the end of year 4 , about 82 percent of net costs are paid compared to about 72 percent for total payments. The faster pattern for net costs reflects the fact that recoveries tend to come later than payments. The clear pattern that emerges from the data is that, for both payments and net costs, the vast 
majority of costs to solvency funds occur during the first few years following liquidation.

\subsection{The Time Path of Costs: Long vs. Short Tail Lines}

In this section, we estimate the time paths for payments and net costs and focus on how these costs vary with the types of lines that firms write. For example, we expect that firms that write significant amounts of premiums in long tail lines such as liability coverage and workmen's compensation will take longer to resolve than firms that write premiums predominantly in short tail lines.

We run regressions of the type in specification 1 above, the only difference being that we divide premiums into two categories -- long tail lines and "all other". The lines that are placed into the long category are Workers' Compensation, Medical Malpractice, Products Liability and Other Liability. All other lines are put into the "other" category. ${ }^{12}$ Long tail lines accounted for 36 percent of total premiums written by firms in our sample. Therefore, we estimate:

$$
\text { Payments } 1 \text { - } \alpha_{t} \cdot \text { Other }{ }_{t_{0}} \cdot \mathrm{B}_{\mathrm{f}} \cdot \text { Long }_{t_{0}} \cdot \epsilon_{t t}
$$

for each of the 8 cohorts.

The results are shown in Table 6a. The coefficients on long tail premiums are generally larger and decrease at a slower rate. The slower decline for the long tail lines is exactly what was expected. Firms that write premiums in long tail lines take longer to resolve

12 We thank Sean Mooney for helpful discussion on the relative lengths of lines. 
than firms that write premiums predominantly in short tail lines. In terms of differences in total payments, the sum of the coefficients is also larger for the long tail lines. Using the same methodology as before to calculate the "terminal value" payments (the implied sum of payments after year 9), the total payments in long tail lines are approximately twice as large as those in other lines, as indicated by the ratio of 1.55 to 0.80 (the bottom entries of the first two columns) in Table $6 \mathrm{~b}$.

One possible reason why long tail lines might be associated with higher total costs is that longer tail lines have higher costs in the future that have not been discounted. The data does not support this notion. In order to check for this possibility, we discounted the future payments with a real interest rate of 3 percent. ${ }^{13}$ The results are shown in the third and fourth columns of Table $6 \mathrm{~b}$. Note that the discounted coefficients imply that the total payments per dollar of premiums in long tail lines (1.36) are still almost twice as high as the total payments associated with other lines (.76).

The same results with net costs substituted for payments are reported in Tables $7 \mathrm{a}$ and 7b. The results are quite similar and consistent with expectations. The total costs associated with long tail lines are again larger than those associated with short tail lines; in fact, the total net costs per dollar of premiums in long tail lines are more than twice as large as net costs in short tail lines, both when costs are in 1993 dollars and when costs are discounted by the real interest rate. Again, the coefficients imply a more slowly declining path for long tail lines than other lines. Note that there are two negative coefficients (in years 6 and 8 ) in the other

13 We chose this rate because it is slightly higher than the average real rate of 2.5 percent on treasury bills during the past ten years, the time period of our data. 
premium category. Though these coefficients are not statistically significant, it is possible for them to be negative since recoveries may exceed costs on average in the out years.

The implied time pattern for payments associated with short and long tail lines are shown in Table 8 and Figure 4 and the analogous pattern for net costs are shown in Table 9 and Figure 5. Again, the striking feature about the estimated time paths is the large divergence between the time path in long tail lines and all other lines. For long tail lines, less than two thirds of payments are made within the first six years. The similar figure for other lines is about 90 percent. For net costs, the difference in time patterns is even more striking. Only 54 percent of net costs in long tail lines occur in the first six years. The analogous figure is 101 percent in all other lines. Again, it is possible for net costs to be negative on average (which produces a cumulative percentage that can exceed 100 percent) if recoveries exceed payments on average during a particular out year. The cumulative percentages should be viewed as rough averages since they are produced by regression coefficients, a few of which are imprecisely estimated. Nevertheless, we are comforted by the fact the implied patterns of the net costs in short and long tail lines are sensible and consistent with the patterns of payments. The important and robust result is that the costs associated with long tail lines have a more slowly declining time path and represent higher total costs per dollar of premium.

\section{Estimates of Costs per Insolvency}

We now use our estimates of the time paths of net costs to produce estimates of the total costs for each insolvency. We start with the cumulative net costs for each insolvency, which we have obtained from the NCIGF. The estimated coefficients from the relevant time 
path regressions (from Table 7a) along with each firm's specific percentages in each of the two premium categories (long and other) implies a unique time path for each insolvency. We use this time path, along with the number of years since liquidation, to estimate the percentage of net costs that have already been incurred for a firm with a certain set of characteristics. ${ }^{14}$ We then combine this information along with the cumulative payments to create a projection of total net costs. Note that to keep multiplicative factors small, we compute projected net costs only for firms that were liquidated at least two full years prior to the last year of our data, 1993. ${ }^{15}$ That is, we wanted to limit the amount of "projection error" by ensuring that add-on net costs for the companies are small relative to already incurred net costs. The companies in this trimmed sample of 87 firms had mean assets of $\$ 57$ million, mean premiums of $\$ 46$ million and mean surplus (i.e. capital) of $\$ 6.5$ million.

A hypothetical example should help clarify our procedure for estimating net payments/costs. Assume that the cumulative payments at the end of 1993 for a firm that was liquidated five years ago is $\$ 100$. We use the regression coefficients in Table $7 \mathrm{a}$ and the fact that a firm's premium mix was 30 percent long and 70 percent other to determine that after five years, cumulative payments are typically 92 percent of the total for a firm of this type. This implies a multiplicative factor of 1.09 (1 divided by .92), which is used to project total net costs of 109 for this firm.

14 As mentioned earlier, all costs and payments are in 1993 dollars.

15 We identified 137 liquidations involving guarantee fund action occuring between 1996 and 1991. Financial information in the year prior to insolvency was available on the NAIC Annual Statement Database for 87 of these firms. These 87 firms represented $76 \%$ of the net costs incurred to date for firms liquidated between 1986 and 1991. 
As a check on our results, we also used a second procedure for producing payment and cost projections from cumulative costs. With this "additive" procedure, we sum the regression coefficients by line for the remaining years and multiply each sum by the dollar amount of premiums written prior to insolvency. This adjustment factor, used to account for future costs to the fund, is added to 1993 cumulative payments or net costs. ${ }^{16}$ This second additive procedure produced estimated net costs that are very similar to those from the multiplicative procedure. $^{17}$

In Table 10, we report some summary statistics of net costs relative to assets. ${ }^{18}$ The first row shows, for all firms in our sample, the mean of the net cost to asset ratio, with both the multiplicative and the additive scaling methods. These means indicate that the total cost of resolving firms is approximately 100 percent of the value of their assets (measured in the year before they fail), a remarkably large number. This implies that the true value of companies' liabilities are twice the value of their assets when they fail. In a later section, we show that the high ratio of insolvency costs to assets is the result of increasing liabilities (which were underestimated) rather than decreasing assets.

In the next four rows, net cost to asset ratios are reported for sets of firms subdivided

16 The multiplicative procedure is more appropriate if firms with abnormally large or small payments in the early stages of liquidation also experience abnormally large or small costs in the later stages. The additive adjustment procedure is more appropriate if deviations from the normal path in the later stages are uncorrelated with doviations in the earlier stage.

17 In the next section, the "failcost" regressions are estimated with both methods for estimating payments and costs. Not surprisingly, the results are very similar.

18 The results are qualitatively similar if we scale by total preminus rather than assets. We scaled by assets because, as will be argued later, they are less prone to change sharply in the year(s) before insolvency. 
by asset size. The smallest firms tend to have higher costs than the larger firms, but no general pattern exists for the three largest quintiles. In the last three rows, we divide firms according to their fraction of premiums in long tail lines. The results show -- not surprisingly, given our earlier findings -- that those firms with significant amounts of premiums written in long tail lines are more costly to resolve. In fact, the net costs of the firms in the top third of this category are approximately twice as costly as those in the bottom third. We come back to this issue in the next section.

The key finding, however, is that it is very costly to resolve the failures of P\&C insurance companies. Net costs as a fraction of assets appear to be nearly 100 percent of assets, which we note is more than three times larger than the 30 percent estimate for commercial banks and S\&L's (Barth, Bartholemew \& Bradley, 1990; Bovenzie \& Merton, 1988; James, 1991). We discuss the validity of comparisons between resolution cost to asset ratios in insurance companies to banks and insurance companies in section 6 .

\section{The Determinants of Insolvency Costs}

In this section, we seek to determine what are the key, measurable determinants of the size of resolution costs. We use our projections of net costs from section 4 as a measure of the actual net costs of resolving P\&C company failures. Our approach, which follows that of James' (1991) and Bovenzie \& Merton's (1988) studies of the costs of bank failures, is to regress net resolution costs, scaled by total assets, on a vector of variables assumed to affect resolution costs.

The variables that we include as regressors are the fraction of premiums written in long 
tail lines (FRACLONG). We already have established that the longer tail lines have longer resolution times and higher net costs on average. Here, we seek to determine whether the costs are also higher, controlling for a variety of factors.

Next, we include the book value capital (surplus) to assets ratio (CAPRATIO). The coefficient on the book value of the capital (surplus) to assets of the insurer allows us some insight into the magnitude of unrealized losses in the insurer's assets and its book of business. We expect a higher level of (pre-insolvency) reported capital to be associated with a lower cost of insolvency, ceteris paribus. If, however, the reported surplus is an unreliable measure of true capital -- because, for example, insurers systematically overstate the true value of their assets or understate the true level of future losses to avoid regulatory intervention -- then there may not be a strong negative relationship between the capital ratio and subsequent insolvency losses. It is noteworthy that James (1991) found this coefficient to be positive in his study of the costs of bank failures, which he interpreted to be the result of fraudulent reporting of capital.

We also consider how the reason for insolvency affects net costs. We supplemented our dataset with information from the A.M. Best Insolvency Study (1991) on the cause of insurer failures. The Best Study included most of the firms in our study and assigned each insolvency to one of nine categories for the cause of the failure. We include a dummy variables for failures deemed by Best to be caused by FRAUD $(=1)$ or a DISASTER $(=1)$.

We also include several variables that may be correlated with large resolution costs. The first is high premium growth in the year preceding insolvency. As stated in the introduction, the moral hazard problem may be particularly acute for firms on the brink of 
bankruptcy. Such firms may undercut their competitors by offering low prices to write a large volume of premiums. For this reason, we include a dummy variable equal to one if the company's premium growth is in the top quartile of all firms. We measure premium growth two different ways: by growth in total premiums written and earned premiums (an income statement item).

We also include two measures of asset composition that may be correlated with resolution costs. First, it often thought that firms that own a large amount of real estate have riskier asset portfolios. Although the average proportion of real estate held by $\mathrm{P} \& \mathrm{C}$ insurance companies is quite small (3.7\% of assets), we include the fraction of assets in real estate on the right hand side as a crude measure of the riskiness of $P \& C$ asset portfolios. We include the ratio of cash plus short term investments as a measure of the firm's ability to meet obligations to policyholders in the pre-insolvency period.

In addition, high growth in losses may be associated with unusually high costs for the obvious reason that losses erode capital. In theory, this effect should be picked up by the capital ratio. However, high loss growth may also reflect the fact that such firms are engaging is unusually risky behavior that will lead to resolution costs being higher. Thus, we include a dummy variable equal to one if the firm's loss growth is in the top quartile of all firms. Analogous to our measures of fast premium growth, me measure losses in two ways: total losses (from the balance sheet) and incurred losses (from the income statement).

Finally, we control for company size. The summary statistics on net costs from Table 10 indicate that smaller firms have higher net resolution costs (as a fraction of total assets). We therefore include dummy variables, equal to one for each quartile of firms ranked by total 
assets, as right-hand side variables.

The results of these regressions, with various permutations of right hand side variables, are shown in Tables $11 \mathrm{a}$ and $11 \mathrm{~b}$ as models 1-6. Heteroscedasticity-consistent standard errors (White, 1980) are in parentheses. FRACLONG, the fraction of premiums written in long tail lines, is positive and approximately twice as large as its standard error in all six models. This is consistent with our earlier finding that firms with a high FRACLONG have higher net costs on average.

While it is easy to see why firms with a high fraction of premiums in long tail lines have longer resolution times, it does not follow that such firms also have higher average resolution costs. While it is beyond the scope of this paper to investigate why this is the case, one intriguing possibility is a type of moral hazard induced by the solvency fund system: insolvent (and near-insolvent) companies may game the system before they are closed down by the regulators by writing premiums, perhaps at prices below expected costs, in long tail lines. From the insurance company's perspective, the benefit of this policy is an immediate inflow of cash, which enables the company to stay in business and to continue to pay salaries, a potentially important consideration to well-paid managers and executives of the companies. The costs of this policy to the insurance companies are deferred and indefinite payments to claimants. Of course, this gaming of the system is only possible if the regulators are either unable or unwilling to see through this game and to take quick action to close down the company when such gaming is detected.

In contrast to the finding of James with regard to commercial banks, we find a negative and statistically significant coefficient on the capital ratio (CAPRATIO), suggesting that 
measured capital has at least a positive correlation with actual capital, which provides a buffer to losses and should lead, ceteris paribus, to lower levels of net costs to solvency funds. Taken together, our estimated coefficients indicate that a one percentage point increase in the capital ratio decreases the payments to assets ratio by about 0.6 percentage points.

In terms of the A.M. Best rating variables, FRAUD does not seem have any explanatory power on net costs. The coefficient on DISASTER, however, is large, positive and statistically significant. The data suggests that disasters are associated with very large costs to the guarantee funds. They suggest that if the reason for the insolvency is a disaster, the ratio of costs to assets increases by more than five-fold, ceteris paribus. Firms failing because of disasters were small and geographically concentrated. The lack of diversification may have been induced by moral hazard. When the disaster struck, the firms experienced a dramatic upward revision in its losses. This finding may suggest that the costs of resolving firms that failed because of a disaster are so large that these firms should be treated differently. As a quick check on this possibility, we removed firms that failed because of disasters from our sample. However, removal of these firms did not change the our results in a substantive way.

The coefficients on fast total premium growth (model 2) and fast earned premium growth (model 3) are positive as was hypothesized. However, neither coefficient is statistically significant at the 5 percent confidence level. The coefficients on fast total loss growth (model 4) and fast incurred loss growth (model 5) are both positive as was hypothesized and the former is significant at the 5 percent confidence level, indicating that firms that have large losses in the year before insolvency tend to be associated with large costs 
to the solvency funds. Neither of the asset composition variables (model 6) are statistically significant, although the coefficient on the proportion of real estate in the asset portfolio is positive and slightly larger than its standard error. Given the relatively bland nature of the typical asset portfolio of P\&C insurance companies, this result is not that surprising.

The coefficients on the size dummies suggest, as was found earlier, that larger firms tend to have lower cost ratios than smaller firms. This may reflect some economies of scale in the process of liquidating the firm and administering it's claim file. Alternatively, it may be that larger firms, because of their potential for sizable costs to the guarantee funds, are forced into liquidation faster and/or are more closely monitored by regulators prior to insolvency. For the same reason, large firms may be monitored more closely during the insolvency and liquidation proceedings.

In table $11 \mathrm{~b}$, we estimate model 6 with two modifications in order to test our basic results for robustness. ${ }^{19}$ First, we use the additive rather than the multiplicative procedure for determining net costs, as discussed in section 4. Second, we replace net costs expressed in real 1993 dollars with net costs expressed in present discounted value terms, using the same 3 percent (real) discount rate as before. The results are robust to both of these modifications; none of our results are substantively different from our earlier results. Taken together, a few findings stand out. The net costs of resolving P\&C insolvencies (scaled by size) seems to be larger for small firms, poorly capitalized firms, firms writing significant amounts in long tail lines, and firms that fail because of disasters.

19 The robustness checks of models 1 through 5 yielded the same basic results and are therefore not reported. 


\section{The Reason for Large Insolvency Costs}

Our finding raise the question of why resolution costs are so high given that virtually all of the insurance companies that fail are solvent, in terms of the book value of their capital, in the year before they fail. In this section, we briefly discuss potential reasons for our key finding that the costs incurred by guarantee funds in resolving property and casualty insurer insolvencies are so high -- approximately 100 percent of pre-insolvency assets.

\subsection{Assets, Liabilities or Administrative Costs?}

In an accounting sense, there are three possibilities for such high resolution costs. First, assets may be the cause; assets may fall sharply and/or be way overstated. Second, liabilities may be the cause; liabilities may increase sharply and/or be hugely understated. And third, there may be very large administrative, legal and other costs associated with resolving insolvencies. Answering this question definitively is beyond the scope of this paper. Nor do we have the necessary data to easily answer it; once a company is declared insolvent, it is removed from the NAIC data base. We suspect, however, that resolution costs are so high because failed firms drastically underestimated their (expected) liabilities -- that is, postinsolvency liabilities typically are about twice the size of the pre-insolvency reported liabilities. We provide some evidence that is supportive of this contention.

Our main reason for suspecting that costs are so high because liabilities rise sharply (except for the disaster-induced failures, this is probably because liabilities were previously understated) is that the other two possibilities seem unlikely. With regard to the 
administrative cost possibility, we do have some data for the eight states, mostly in New England, that are managed by the Boston-based Guarantee Fund Management Services. The total administrative costs - office, salaries, lawyers fees etc. -- for the eight state funds they administer averaged about $\$ 8$ million dollars annually since 1991. These administrative costs represent approximately 16 percent of the annual costs to the guarantee fund for these eight states. While it is difficult to know whether this number is unreasonably high or not, it seems unlikely that administrative costs account for a significant portion of the large resolution costs that we estimate.

The other possibility, that the large costs we estimate are associated with overstated and/or large decreases in assets, also seems unlikely. Approximately, 10 percent of P\&C assets are in the form of cash or other liquid assets and 60 percent is in bonds of some sort. 15 percent is in common and preferred stock. The remainder consists of recievables and tangible assets such as the firm's own buildings and data processing equipment. While these assets can certainly fall in value, it is virtually impossible for them to fall enough to produce our resolution cost estimates. An example can illustrate why this is the case. For simplicity, assume that book assets are approximately equal to liabilities when the firm becomes insolvent (assets are actually higher, which makes are case stronger). If liabilities do not change, and assuming away administrative costs, assets would have to fall to zero in order to produce resolution costs equal to the value of pre-insolvency book assets. It seems extremely unlikely that assets fall to zero or anywhere close to that much. A much more likely scenario involves increases in liabilities associated with huge (pre- and post-insolvency) losses.

One piece of evidence for the view that problem liablities rather than problem assets 
cause insurance company failures is the fact that investment income is positive for the firms in our sample (averaging $\$ 3.6$ million) in the year prior to insolvency, while underwriting income is negative (averaging $-\$ 10.4$ million).

In addition, to get a sense of how assets and liabilities change, we looked at the change in total assets, liabilities, loss reserves (a liability that estimates future losses) and losses incurred during the year (from the income statement) between one and two years prior to insolvency. The mean of the annual percentage change for each of these variables is shown in Table 12. The results are consistent with our expectations. In the year prior to insolvency, assets fell by only 1.3 percent while liabilities increased by 14.5 percent. Loss reserves and annual losses increased by 18.7 and 26.0 percent respectively. It seems likely that the continuance of these trends, and not a sharp decline in assets, is what accounts for the large resolution costs that we are estimating.

\subsection{A Comparison with Bank Insolvency Costs}

While insurance companies tend to fail because of rising (and/or previously understated) liabilities, banks tend to fail because of loan defaults. That is, to a first approximation, banks fail because of asset problems while insurance companies fail because of liability problems. This fact makes our comparison of bank and insurance company resolution costs more than fair: because our cost measures are relative to pre-insolvency assets (which are more likely to be falling sharply for banks), our finding that the cost to asset ratio is much higher for insurance companies is even more striking.

The large difference in resolution costs between insurers and depository institutions 
may be because of differences in the nature of the businesses of these institutions. Although banks make loans that are risky, these risks may be smaller on average than the risks inherent to the insurance business where the costs of production of the product (policyholder losses) are unknown at the time the product is sold. In such a situation, bad business judgment or opportunistic behavior on the part of management can be particularly costly. Indeed, we find resolution costs to be particularly among firms writing large amounts of premiums in long tail lines in which the value of future losses are particularly difficult to estimate. In addition, the resolution cost differential between banks and insurance companies may reflect differences in the way that these financial institutions are resolved. While insolvent banks are typically liquidated and/or quickly merged with healthy institutions, insurance company assets are liquidated and the liabilities are assumed by guaranee fund management agencies. Essentially, insurance regulatory bodies operating through the fund management systems take over the insolvent companies and run them until all claims have been paid.

\section{Conclusion}

We examine the costs of resolving Property and Casualty insurance company insolvencies. When a Property and Casualty (P\&C) insurance company becomes insolvent, solvent insurance companies are forced to pay assessments, which are a form of taxation, to state guarantee funds in order to protect the policyholders of the failed companies. Our estimates imply that the costs incurred by guarantee funds to resolve insurance company insolvencies are remarkably high -- about 100 percent of the book value of the assets in the year before the company was declared to be insolvent. This implies that insolvent companies 
have liabilities that are approximately twice as large as their assets when they are declared to be insolvent. These costs are more than three times as high as the costs incurred by the FDIC and FSLIC in resolving the failures of commercial banks and S\&L's in the 1980s.

We also find that the ratio of net costs to assets tends to be higher for small firms, poorly capitalized firms, firms writing significant premiums in long tail lines, and firms that fail because of disasters. Our findings also indicate that the resolution of insolvencies is typically quick. More than 60 percent of all costs to the fund for a given insolvency occur within two years, and more than three-quarters of total costs occur within three years. However, we find that firms with a high proportion of premiums in long tail lines take much longer to resolve, perhaps because companies are gaming the solvency fund system, a type of moral hazard.

There are a variety of questions that are raised by our findings. Although we have tried to shed some light on the subject, understanding why the costs of resolving insurance company failures are so high remains something of a mystery. To what extent do the moral hazard effects created by the solvency fund system lead to the large costs? Are firms gaming the system by writing premiums in long tail lines at below expected costs? Are some companies writing high-risk premiums in geographically concentrated areas? Are the high resolution costs in insurance companies relative to banks the result of the differing ways in which these insolvent institutions are resolved. Determining the reasons for the high cost of resolving $\mathbf{P} \& C$ insurance companies is an important topic for future research.

In addition, our finding of high resolution costs raises the issue of to what extent the solvency funds are "exposed" to various shocks (eg. natural disasters) that may lead to very 
large "assessments" against healthy firms. What scenarios would cause the solvency fund assessments to reach their maximum levels, typically one to two percent of premiums per year? How exposed is the system to a very large shock or set of shocks that has the potential to create and S\&L like problem in the P\&C insurance industry? All of these questions should be high priorities for future research. 


\section{References}

A.M. Best Company, 1991, Best's Insolvency Study, Oldwick, N.J., A.M. Best Company.

Barth, J., P. Bartholemew, and M. Bradley, 1991, Determinants of Thrift Resolution Costs, Journal of Finance, 45, 731-754.

Besley, D. A., E. Kuh and R.E. Welsch, 1980, Regression Diagnostics, New York: John Wiley and Sons, Inc.

Bovenzie, J. and A. Murton, 1988, Resolution Costs and Bank Failures, FDIC Banking Review, 1-13.

Clarke, R.N., F. Warren-Bolton, D.K. Smith, and M.J. Simon, Sources of the crisis in liability insurance: An empirical analysis, Yale Journal on Regulation, Summer 1988, $367-95$.

Cummins, J., 1988, Risk Based Premiums for Insurance Guarantee Funds, Journal of Finance, 43, 823-839.

Duncan, M., 1987, Property-Liability Post Assessment Guarantee Funds, in Issues in Insurance, 4 th ed., 239-302.

Epton, B and R. Bixby, 1976, Insurance Guarantee Funds: A Reassessment, DePaul Law Review, 25, 227-263.

Hall, D. and R. Hall, 1993, Insurance Company Insolvencies: Order Out of Chaos, Journal of Insurance Regulation, 12, 145-187.

Hiestand, J., 1986, the Need for Revision of State Insolvency and Guarantee Funds Laws, 563-609, in Law and Practice of Insurance Insolvency, American Bar Association.

Insurance Information Institute, 1993, The Fact Book 1993: Property/Casualty Insurance Facts, Insurance Information Institute, New York.

James, C., 1991, The Losses Realized in Bank Failures, Journal of Finance, 46, 1223-1242.

National Conference of Insurance Guarantee Funds, 1993a, Property/Casualty Guarantee Association 1993 Assessment and Financial Information Report, mimeo.

National Conference of Insurance Guarantee Funds, 1993b, 1993 Summary of Property and Casualty Guarantee Association Acts, mimeo. 
Schacht, J. and P. Gallonis, The Interstate Compact as an Effective Mechanism for Insurance Receivership Reform, Jillmal of Insurance Regulation, 12, 188-220.

U.S. House of Representatives, Subcommittee on Oversight and Investigations of the Committe on Energy and Commerce, Failed Promises: Insurance Company Insolvencies, Washington, D.C., U.S. Government Printing Office, 1990. 
Figure I

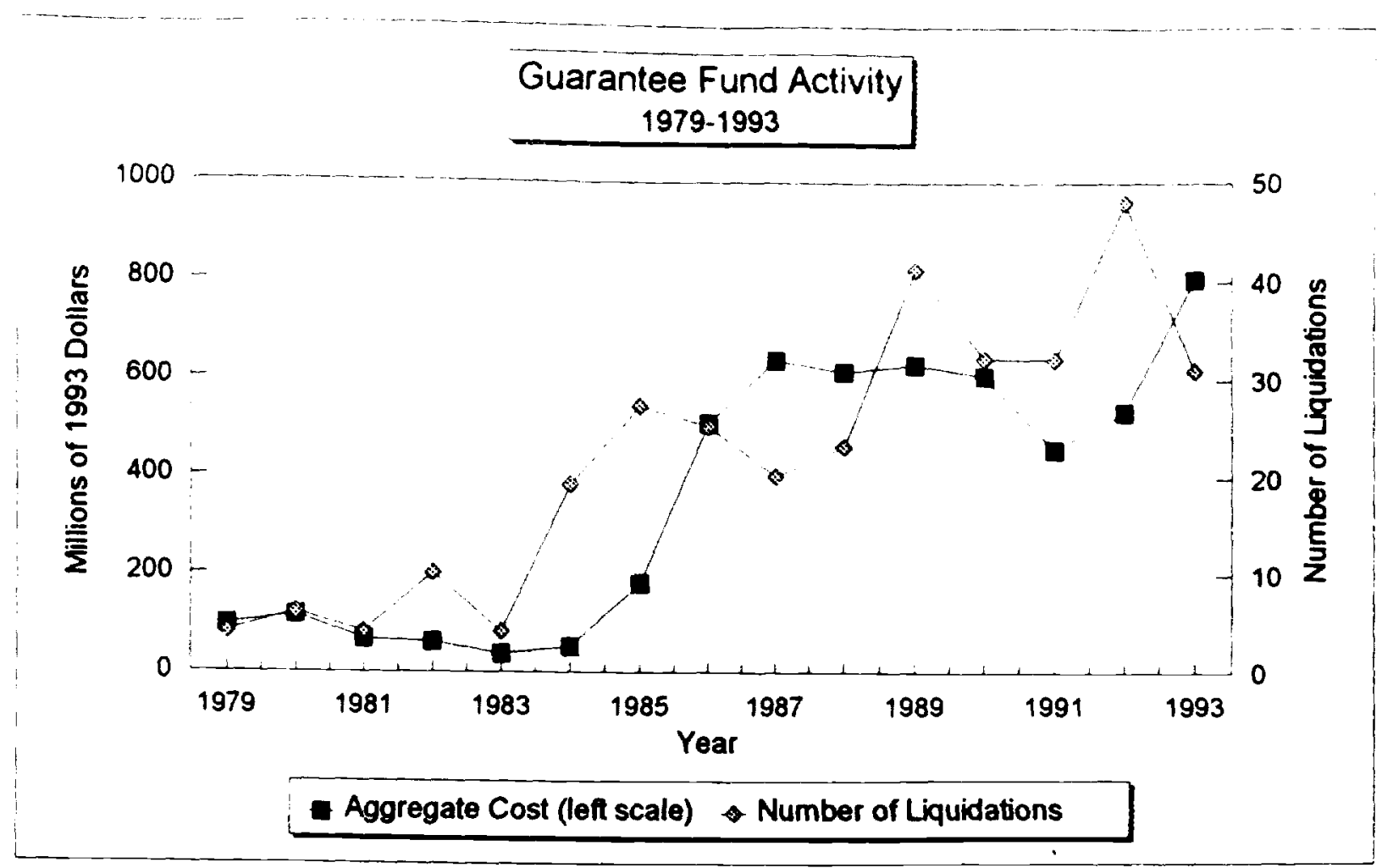


Table 1

Payments $_{\mathrm{it}}=\alpha_{\mathrm{t}}^{*}$ Premiums $_{\mathrm{tto}}+\epsilon_{\mathrm{it}}$

\begin{tabular}{|c|c|c|c|}
\hline Year & Premiums & $\operatorname{Adj} R^{2}$ & $N$ \\
\hline 1 & $\begin{array}{r}.2524 \\
(.1128) \\
\end{array}$ & .0733 & 51 \\
\hline 2 & $\begin{array}{r}.2724 \\
(.0379) \\
\end{array}$ & .3445 & 51 \\
\hline 3 & $\begin{array}{c}.1363 \\
(.0104) \\
\end{array}$ & .9157 & 30 \\
\hline 4 & $\begin{array}{c}.0585 \\
(.0178) \\
\end{array}$ & .6111 & 34 \\
\hline 5 & $\begin{array}{c}.0164 \\
(.0043) \\
\end{array}$ & .5106 & 34 \\
\hline 6 & $\begin{array}{c}.0606 \\
(.0085) \\
\end{array}$ & .8111 & 23 \\
\hline 7 & $\begin{array}{c}.0605 \\
(.0073) \\
\end{array}$ & .8231 & 23 \\
\hline 8 & $\begin{array}{c}.0365 \\
(.0067) \\
\end{array}$ & .6195 & 23 \\
\hline $\begin{array}{c}\text { Sum of } \\
\text { Coefficients }\end{array}$ & .8936 & & \\
\hline Year $9 \&$ after & .1100 & & \\
\hline Total Costs & 1.0036 & & \\
\hline
\end{tabular}

Notes: Heteroscedasticity consistent standard errors are in parentheses.

$I=$ firm index $(I=1, \ldots, n)$

$\mathrm{t}=$ year relative to liquidation date $(\mathrm{t}=1, \ldots, 8)$.

$t_{\mathrm{o}}=$ year prior to insolvency.

Models were estimated seperately for each $t$. Liquidation proceedings commence in year
$t=1$. 
Table 2

Payments $_{93}=\alpha_{1}^{*}$ Payments $_{s_{2}}+\epsilon_{r}$

\begin{tabular}{|c|c|c|c|}
\hline Year & Payments $_{92}$ & Adj $^{2}$ & Obs \\
\hline 1 & $\cdots-\ldots$ & $\ldots$ & \\
\hline 2 & $\begin{array}{c}1.2454 \\
(.3457)\end{array}$ & .7411 & 43 \\
\hline 3 & $\begin{array}{c}.5743 \\
(.0214)\end{array}$ & .9679 & 26 \\
\hline 4 & $\begin{array}{c}.4887 \\
(.0674)\end{array}$ & .8911 & 24 \\
\hline 5 & $\begin{array}{c}.8742 \\
(.0911)\end{array}$ & .9385 & 29 \\
\hline 6 & $\begin{array}{c}.6259 \\
(.1192)\end{array}$ & .8777 & 18 \\
\hline 7 & $\begin{array}{c}.7920 \\
(.0891)\end{array}$ & .9552 & 14 \\
\hline 8 & $\begin{array}{c}.7282 \\
(.0552)\end{array}$ & .9032 & 23 \\
\hline
\end{tabular}

Notes: Heteroscedasticity consistent standard errors are in parentheses.

$I=$ firm index $(I=1, \ldots, n)$

$t=$ year relative to liquidation date $(t=1, \ldots, 8)$.

$t_{0}=$ year prior to insolvency.

Models were estimated separately for each $t$. Liquidation proceedings commence in year $\mathrm{t}=1$. 
Table 3 Payments made by the end of year $\mathrm{n}$ as a percentage of implied total payments to resolve the
insolvency.

\begin{tabular}{|c|c|c|c||}
\hline \multicolumn{2}{|c|}{$\begin{array}{c}\text { From Total Premiums Regressions } \\
\text { (Specification 1) }\end{array}$} & \multicolumn{2}{c|}{$\begin{array}{c}\text { From Regression on Previous } \\
\text { Payments } \\
\text { (Specification 2) }\end{array}$} \\
\hline Year & cum. percent & Year & cum. percent \\
\hline 1 & $25.2 \%$ & 1 & $23.3 \%$ \\
\hline 2 & 52.3 & 2 & 52.2 \\
\hline 3 & 65.9 & 3 & 68.8 \\
\hline 4 & 71.7 & 4 & 77.0 \\
\hline 5 & 73.3 & 5 & 84.1 \\
\hline 6 & 79.4 & 6 & 88.5 \\
\hline 7 & 85.4 & 7 & 92.0 \\
\hline 8 & 89.0 & 8 & 94.6 \\
\hline
\end{tabular}

Figure 2

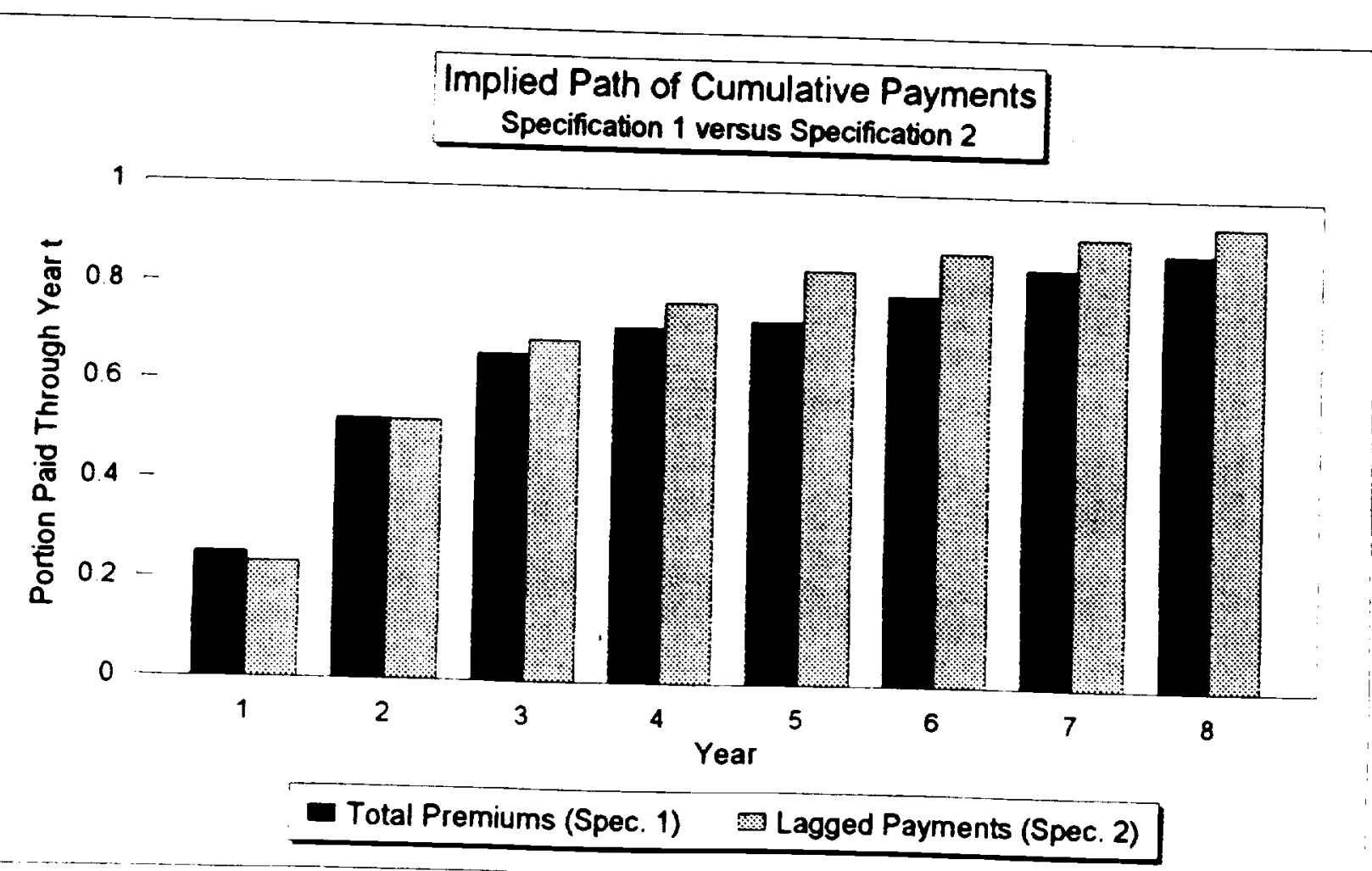


Table 4

Net Cost $_{\mathrm{tt}}=\alpha_{\mathrm{t}}{ }^{*}$ Premiums $_{\mathrm{tto}}+\epsilon_{\mathrm{i}}$

\begin{tabular}{|c|c|c|c|}
\hline Year & Premiums & Adj $R^{2}$ & $\mathrm{~N}$ \\
\hline 1 & $\begin{array}{r}.2496 \\
(.1124) \\
\end{array}$ & .0732 & 51 \\
\hline 2 & $\begin{array}{r}.2608 \\
(.0365) \\
\end{array}$ & .3524 & 51 \\
\hline 3 & $\begin{array}{r}.1269 \\
(.0125) \\
\end{array}$ & .8589 & 30 \\
\hline 4 & $\begin{array}{l}.0356 \\
(.0203) \\
\end{array}$ & .3410 & 34 \\
\hline 5 & $\begin{array}{c}.0115 \\
(.0029) \\
\end{array}$ & .4186 & 34 \\
\hline 6 & $\begin{array}{r}-.0118 \\
(.0365) \\
\end{array}$ & -.0178 & 22 \\
\hline 7 & $\begin{array}{c}.0506 \\
(.0059) \\
\end{array}$ & .7563 & 23 \\
\hline 8 & $\begin{array}{c}.0252 \\
(.0124)\end{array}$ & .3233 & 23 \\
\hline $\begin{array}{c}\text { Sum of Coefficients } \\
\text { Years } 1-8\end{array}$ & .7487 & & \\
\hline Year $9 \&$ after & .0750 & & \\
\hline Total Net Costs & .8234 & & \\
\hline
\end{tabular}

Notes: Heteroscedasticity consistent standard errors are in parentheses.

$I=$ firm index $(I=1, \ldots, n)$

$t=$ year relative to liquidation date $(t=1, \ldots, 8)$.

$t_{\mathrm{o}}=$ year prior to insolvency.

Models were estimated separately for each $t$. Liquidation proceedings commence in year 
Table 5

\begin{tabular}{|c|c|c|}
\hline \multicolumn{3}{|c|}{ Cumulative Percent } \\
\hline Year & Net Costs & Payments \\
\hline 1 & 30.3 & 25.2 \\
\hline 2 & 62.0 & 52.3 \\
\hline 3 & 77.4 & 65.9 \\
\hline 4 & 81.7 & 71.7 \\
\hline 5 & 83.1 & 73.3 \\
\hline 6 & 81.7 & 79.4 \\
\hline 7 & 87.8 & 85.4 \\
\hline 8 & 90.9 & 89.0 \\
\hline
\end{tabular}

Costs/Payments made by the end of year $n$ as a percentage of implied total payments to resolve the insolvency.

Figure 3

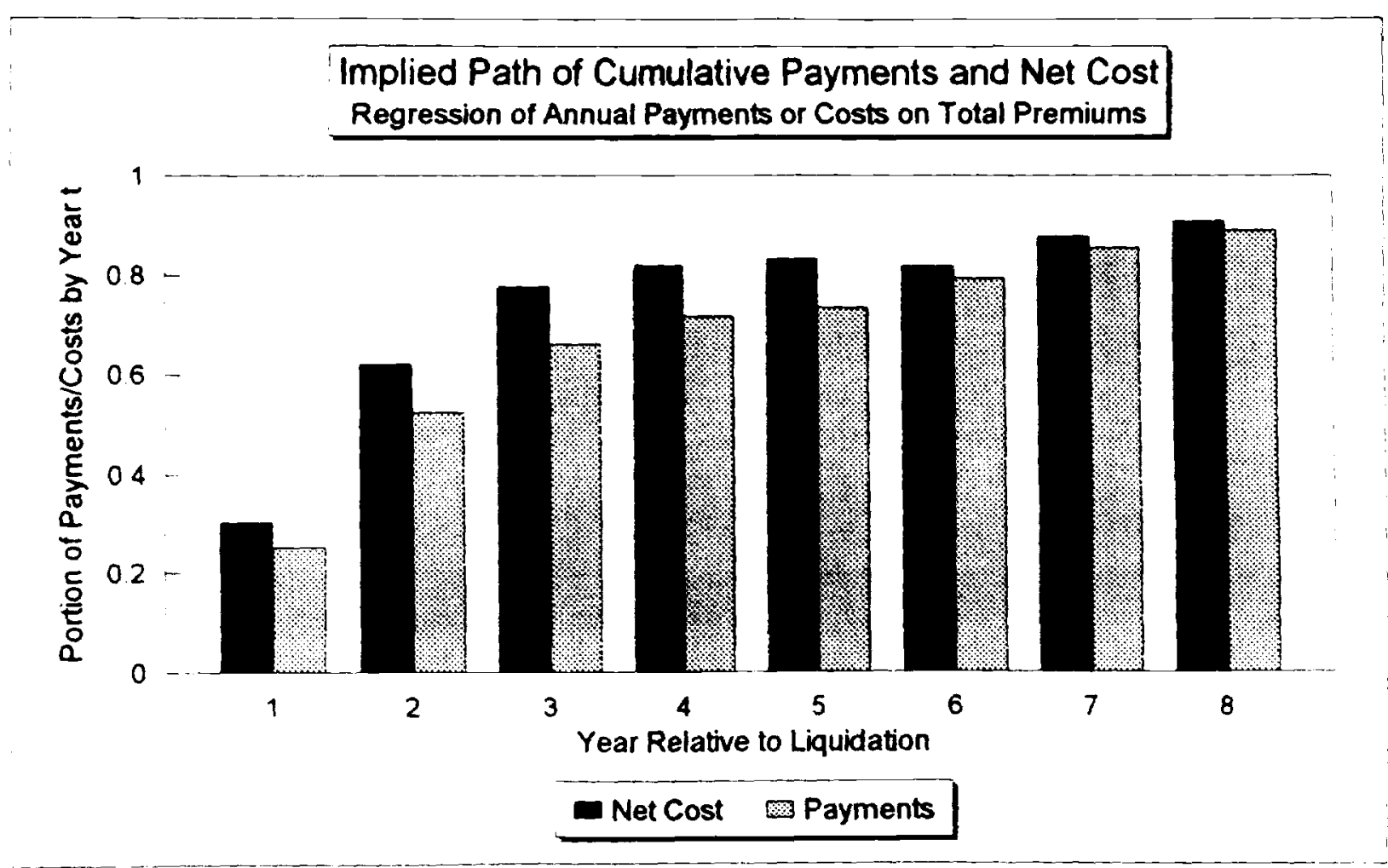


Table 6a

\begin{tabular}{|c|c|c|c|c|}
\hline Year & Long Tail & All Other & Adj $R^{2}$ & $\mathrm{~N}$ \\
\hline 1 & $\begin{array}{l}.3675 \\
(.5969)\end{array}$ & $\begin{array}{l}.2219 \\
(.1199)\end{array}$ & .0557 & 51 \\
\hline 2 & $\begin{array}{c}.2501 \\
(.0106)\end{array}$ & $\begin{array}{l}.3103 \\
(.1215)\end{array}$ & .3344 & 51 \\
\hline 3 & $\begin{array}{l}.1569 \\
(.0083)\end{array}$ & $\begin{array}{l}.0987 \\
(.0102)\end{array}$ & .9457 & 30 \\
\hline 4 & $\begin{array}{l}.0834 \\
(.0315)\end{array}$ & $\begin{array}{l}.0536 \\
(.0223)\end{array}$ & .6133 & 35 \\
\hline 5 & $\begin{array}{l}.0182 \\
(.0069)\end{array}$ & $\begin{array}{l}.0161 \\
(.0050)\end{array}$ & .4959 & 35 \\
\hline 6 & $\begin{array}{l}.0955 \\
(.0072)\end{array}$ & $\begin{array}{l}.0168 \\
(.0103)\end{array}$ & .8925 & 23 \\
\hline 7 & $\begin{array}{l}.0736 \\
(.0117)\end{array}$ & $\begin{array}{l}.0423 \\
(.0268)\end{array}$ & .8189 & 23 \\
\hline 8 & $\begin{array}{l}.1192 \\
(.0426)\end{array}$ & $\begin{array}{l}.0044 \\
(.0112)\end{array}$ & .7764 & 23 \\
\hline $\begin{array}{c}\text { Sum of Coefficients } \\
\text { Years } 1-8\end{array}$ & 1.1644 & .7641 & & \\
\hline
\end{tabular}

Table 6b

Expected Guaranty Fund Payments per Dollar of Direct Premiums Written

\begin{tabular}{|c|c|c|c|c|}
\hline & \multicolumn{2}{|c|}{} & \multicolumn{2}{|c|}{$\begin{array}{c}\text { Present Discounted Value of } \\
\text { Payments Assuming a 3.00\% } \\
\text { Real Interest Rate }\end{array}$} \\
\hline & Lotal Payments in 1993 Dollars & $\begin{array}{c}\text { Ail Lines } \\
\text { All Other }\end{array}$ & Long Tail Lines & All Other \\
\hline First 8 years & 1.1644 & 0.7641 & 1.0900 & 0.7330 \\
\hline Year 9 \& after & 0.3896 & 0.0369 & 0.2710 & 0.0282 \\
\hline Total Payments & 1.5440 & 0.8010 & 1.3610 & 0.7613 \\
\hline
\end{tabular}


Table 7a

Net Cost $=\alpha_{1}^{*}$ Other $_{10}+\beta_{1}^{*}$ Long $_{10}+\epsilon_{11}$

\begin{tabular}{|c|c|c|c|c|}
\hline Year & Long Tai & All Other & Adj $R$ & $\mathrm{~N}$ \\
\hline 1 & $\begin{array}{c}.3746 \\
(.5963)\end{array}$ & $\begin{array}{c}.2165 \\
(.1192)\end{array}$ & 0.0558 & 51 \\
\hline 2 & $\begin{array}{c}.2400 \\
(.0090)\end{array}$ & $\begin{array}{c}.2961 \\
(.1163)\end{array}$ & 0.3424 & 51 \\
\hline 3 & $\begin{array}{c}.1486 \\
(.0078)\end{array}$ & $\begin{array}{l}.0871 \\
(0087)\end{array}$ & 0.8940 & 30 \\
\hline 4 & $\begin{array}{c}.0760 \\
(.0258)\end{array}$ & $\begin{array}{c}.0277 \\
(.0245)\end{array}$ & 0.3797 & 34 \\
\hline 5 & $\begin{array}{c}.0035 \\
(.0033)\end{array}$ & $\begin{array}{c}.0126 \\
(.0034)\end{array}$ & 0.4213 & 34 \\
\hline 6 & $\begin{array}{c}.0032 \\
(.0671)\end{array}$ & $\begin{array}{c}-.0305 \\
(.0254)\end{array}$ & -0.0532 & 22 \\
\hline 7 & $\begin{array}{c}.0738 \\
(.0127)\end{array}$ & $\begin{array}{c}.0123 \\
(.0289)\end{array}$ & 0.7693 & 23 \\
\hline 8 & $\begin{array}{c}.1379 \\
(.0389)\end{array}$ & $\begin{array}{c}-.0186 \\
(.0174)\end{array}$ & 0.6688 & 23 \\
\hline $\begin{array}{c}\text { Sum of } \\
\text { Coefficients }\end{array}$ & 1.0576 & .6032 & & \\
\hline
\end{tabular}

Table 7b

Expected Resolution Costs per Dollar of Direct Premiums Written

\begin{tabular}{|c|c|c|c|c|}
\hline & \multicolumn{2}{|l|}{ Total Payments in 1993 Dollars } & \multicolumn{2}{|c|}{$\begin{array}{c}\text { Present Discounted Value of } \\
\text { Payments Assuming a 3.00\% } \\
\text { Real Interest Rate }\end{array}$} \\
\hline & Long Tail Lines & All Other & Long Tail Lines & All Other \\
\hline First 8 years & 1.0576 & 0.6032 & 0.9970 & 0.5915 \\
\hline Year 9 \& after & 0.5028 & 0 & 0.3426 & 0 \\
\hline Total & 1.5604 & 0.6032 & 1.3396 & 0.5915 \\
\hline
\end{tabular}


Table 8

Percentage of total payments incurred by the end of year $t$.

\begin{tabular}{|c|c|c|}
\hline \multirow{2}{*}{ Year } & \multicolumn{2}{|c|}{ Cum. Percent in Payments Series } \\
\cline { 2 - 3 } & Long Tail Lines & All Other Lines \\
\hline 1 & $23.68 \%$ & $27.70 \%$ \\
\hline 2 & 39.79 & 66.44 \\
\hline 3 & 49.90 & 78.76 \\
\hline 4 & 55.28 & 85.46 \\
\hline 5 & 56.46 & 87.47 \\
\hline 6 & 62.61 & 89.56 \\
\hline 7 & 67.22 & 94.84 \\
\hline 8 & 74.90 & 95.39 \\
\hline
\end{tabular}

Figure 4

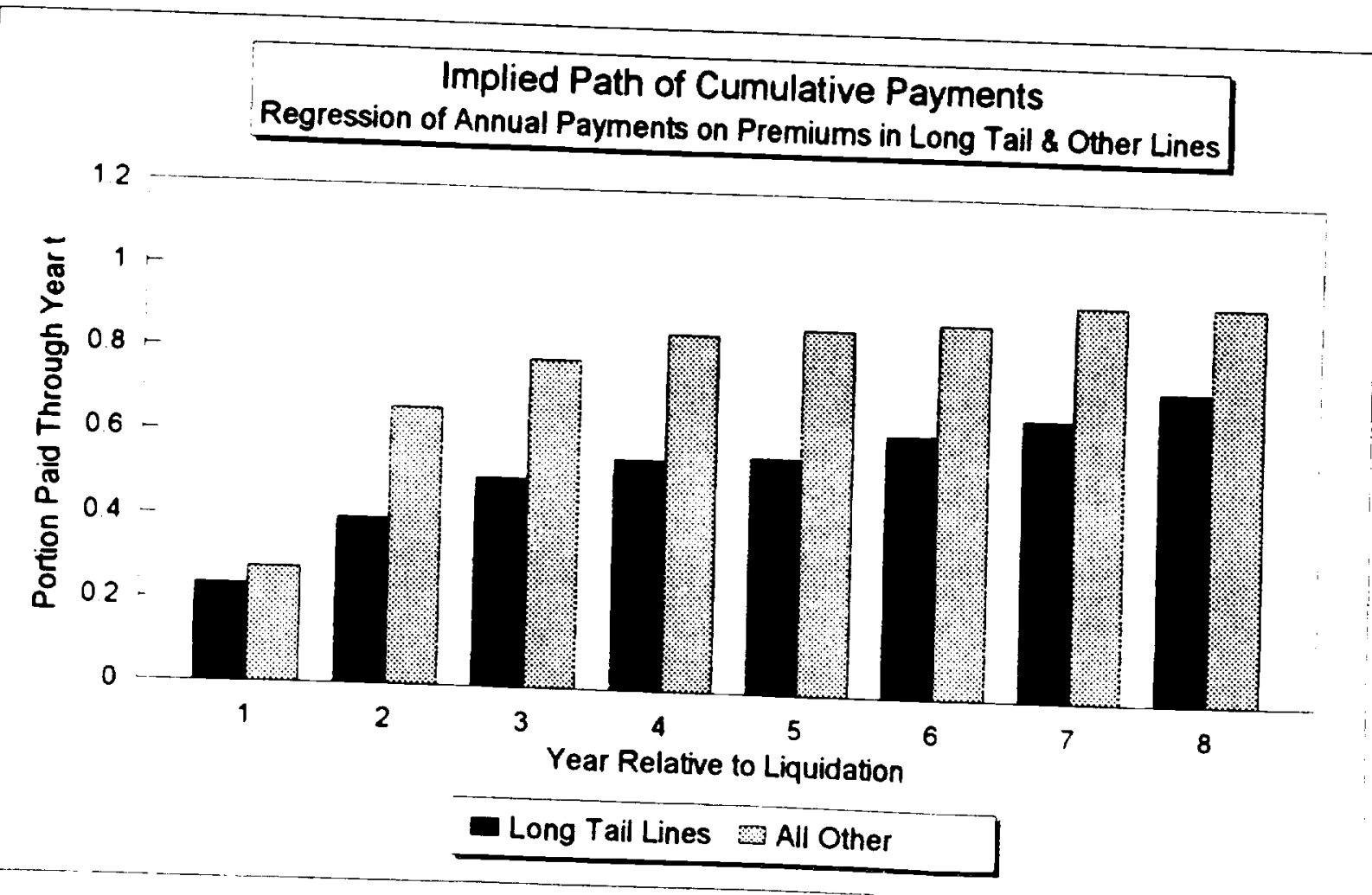


Table 9

Percentage of total costs incurred by the end of year $t$.

\begin{tabular}{|c|c|c|}
\hline \multirow{2}{*}{ Year } & \multicolumn{2}{|c|}{ Cum. Percent in Net Cost Series } \\
\cline { 2 - 3 } & Long Tail Lines & All Other Lines \\
\hline 1 & $24.01 \%$ & $35.89 \%$ \\
\hline 2 & 39.39 & 84.98 \\
\hline 3 & 48.91 & 99.42 \\
\hline 4 & 53.78 & 104.01 \\
\hline 5 & 54.00 & 106.10 \\
\hline 6 & 54.21 & 101.04 \\
\hline 7 & 58.94 & 103.08 \\
\hline 8 & 67.78 & 100.00 \\
\hline
\end{tabular}

Figure 5

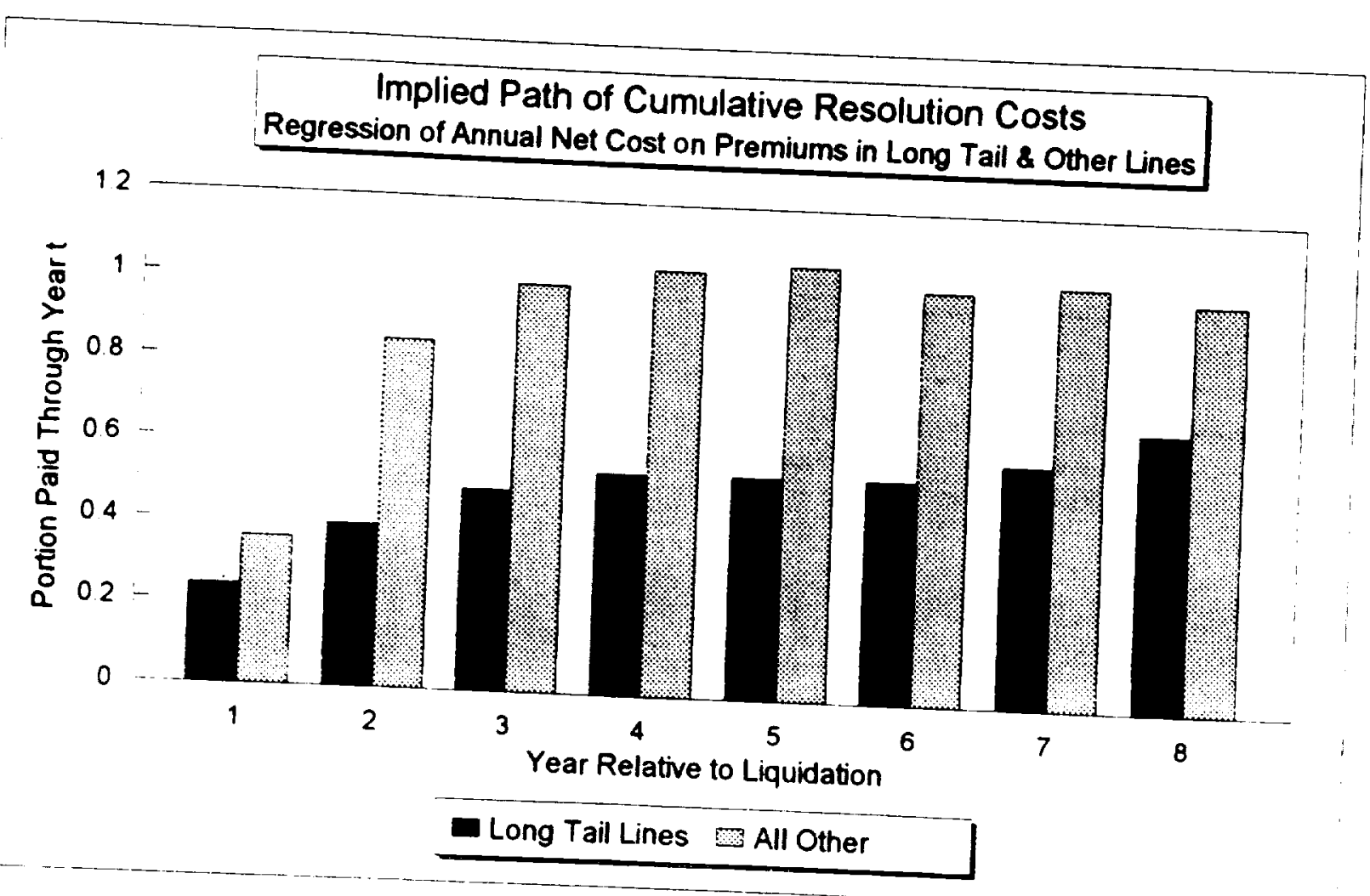


Table 10

Mean Value of Net Cost as a Percentage of Assets

\begin{tabular}{|l|c|c|l|l|}
\hline & & & $\begin{array}{l}\text { Multiplicative } \\
\text { Scaling }\end{array}$ & Additive Scaling \\
\hline Sample of firms & $\begin{array}{l}\text { Number } \\
\text { of firms }\end{array}$ & & $\begin{array}{l}\text { costs/ } \\
\text { assets }\end{array}$ & $\begin{array}{l}\text { costs/ } \\
\text { assets }\end{array}$ \\
\hline All Firms & 87 & & 1.024 & 1.032 \\
\hline \hline Company Asset Size & & $\begin{array}{c}\text { Mean } \\
\text { Assets }\end{array}$ & & \\
\hline 1 smallest & 21 & $2.9 \mathrm{~m}$ & 2.127 & 2.078 \\
\hline 2 & 22 & $13.0 \mathrm{~m}$ & .773 & .797 \\
\hline 3 & 22 & $32.4 \mathrm{~m}$ & .558 & .550 \\
\hline 4 largest & 22 & $176.6 \mathrm{~m}$ & .690 & .748 \\
\hline \hline $\begin{array}{l}\text { Fraction of premiums in } \\
\text { long tail lines }\end{array}$ & & $\begin{array}{c}\text { Mean } \\
\text { Fraction }\end{array}$ & & \\
\hline 1 lowest fraction & 29 & .000 & .752 & .754 \\
\hline 2 & 29 & .048 & 1.031 & 1.046 \\
\hline 3 highest fraction & 29 & .698 & 1.290 & 1.296 \\
\hline
\end{tabular}


Table lla

FAILCOST regressions

Standard errors in parentheses

\begin{tabular}{|c|c|c|c|c|}
\hline & Model 1 & Model 2 & Model 3 & Model 4 \\
\hline Observations & 87 & 71 & 69 & 67 \\
\hline Adj R-square & .3884 & 0.4122 & 0.4127 & 0.5788 \\
\hline intercept & $\begin{array}{r}1.5320 \\
(.3734) \\
\end{array}$ & $\begin{array}{r}1.3548 \\
(.3129) \\
\end{array}$ & $\begin{array}{r}1.4713 \\
(.3287) \\
\end{array}$ & $\begin{array}{r}1.2371 \\
(.2978) \\
\end{array}$ \\
\hline FRACLONG & $\begin{array}{l}1.5179 \\
(.8365) \\
\end{array}$ & $\begin{array}{r}1.7231 \\
(.8537) \\
\end{array}$ & $\begin{array}{l}1.6600 \\
(.8115) \\
\end{array}$ & $\begin{array}{r}1.2209 \\
(.4954) \\
\end{array}$ \\
\hline CAPRATIO & $\begin{array}{r}-.6133 \\
(.2241) \\
\end{array}$ & $\begin{array}{l}-.5951 \\
(.2436) \\
\end{array}$ & $\begin{array}{r}-.5552 \\
(.2532) \\
\end{array}$ & $\begin{array}{r}-.5355 \\
(.1847) \\
\end{array}$ \\
\hline FRAUD & $\begin{array}{c}.0780 \\
(.2678) \\
\end{array}$ & $\begin{array}{r}-.3317 \\
(.3331) \\
\end{array}$ & $\begin{array}{c}.3442 \\
(.3272) \\
\end{array}$ & $\begin{array}{c}.3071 \\
(.3145) \\
\end{array}$ \\
\hline DISASTER & $\begin{array}{r}5.4335 \\
(1.8345) \\
\end{array}$ & $\begin{array}{r}5.6018 \\
(1.8196) \\
\end{array}$ & $\begin{array}{r}5.4692 \\
(1.8268) \\
\end{array}$ & $\begin{array}{r}5.4005 \\
(1.6045) \\
\end{array}$ \\
\hline $\begin{array}{l}\text { Fast Growth in } \\
\text { Total Premiums }\end{array}$ & & $\begin{array}{r}.4804 \\
(.3900) \\
\end{array}$ & & \\
\hline $\begin{array}{c}\text { Fast Earned- } \\
\text { Premium Growth }\end{array}$ & & & $\begin{array}{c}.5401 \\
(.4235) \\
\end{array}$ & \\
\hline $\begin{array}{c}\text { Fast Growth in } \\
\text { Total Losses }\end{array}$ & & & & $\begin{array}{c}.5950 \\
(.2281) \\
\end{array}$ \\
\hline Asset size 2 & $\begin{array}{r}-.8445 \\
(.5066) \\
\end{array}$ & $\begin{array}{r}-1.7483 \\
(.4669) \\
\end{array}$ & $\begin{array}{r}-.9145 \\
(.5438) \\
\end{array}$ & $\begin{array}{r}-.5855 \\
(.3444) \\
\end{array}$ \\
\hline Asset size 3 & $\begin{array}{r}-1.2306 \\
(.5455) \\
\end{array}$ & $\begin{array}{r}-1.3653 \\
(.5609) \\
\end{array}$ & $\begin{array}{r}-1.4902 \\
(.6123) \\
\end{array}$ & $\begin{array}{r}-1.1441 \\
(.4095) \\
\end{array}$ \\
\hline Asset size 4 & $\begin{array}{r}-1.5478 \\
(.7607) \\
\end{array}$ & $\begin{array}{r}-1.4312 \\
(.6983) \\
\end{array}$ & $\begin{array}{r}-1.5577 \\
(.7204) \\
\end{array}$ & $\begin{array}{l}-1.1902 \\
(.5194) \\
\end{array}$ \\
\hline
\end{tabular}

Note: Heteroscedasticity consistent standard errors in parentheses (White, 1980). 
Table 11b

FAILCOST regressions

Standard errors in parentheses

\begin{tabular}{|c|c|c|c|c|}
\hline & Model 5 & Model 6 & $\begin{array}{l}\text { Model } 6 \text { with } \\
\text { additive scaling }\end{array}$ & $\begin{array}{c}\text { Model } 6 \text { with } \\
\text { discounting }\end{array}$ \\
\hline Observations & 75 & 87 & 87 & 87 \\
\hline Adj R-square & 0.4126 & 0.3801 & 0.4596 & 0.4076 \\
\hline intercept & $\begin{array}{r}1.5035 \\
(.3309) \\
\end{array}$ & $\begin{array}{r}1.6026 \\
(.4109) \\
\end{array}$ & $\begin{array}{r}1.5157 \\
(.3506) \\
\end{array}$ & $\begin{array}{l}1.6821 \\
(.4035) \\
\end{array}$ \\
\hline FRACLONG & $\begin{array}{r}1.5920 \\
(.7895) \\
\end{array}$ & $\begin{array}{r}1.5524 \\
(.8316) \\
\end{array}$ & $\begin{array}{r}1.4670 \\
(.6754) \\
\end{array}$ & $\begin{array}{r}1.3852 \\
(.7927) \\
\end{array}$ \\
\hline CAPRATIO & $\begin{array}{r}-.6724 \\
(.2343) \\
\end{array}$ & $\begin{array}{r}-.5630 \\
(.2369) \\
\end{array}$ & $\begin{array}{r}-.5275 \\
(.1981) \\
\end{array}$ & $\begin{array}{r}-.6367 \\
(.2337) \\
\end{array}$ \\
\hline FRAUD & $\begin{array}{r}-.0467 \\
(.2870) \\
\end{array}$ & $\begin{array}{r}.0986 \\
(.2655) \\
\end{array}$ & $\begin{array}{r}.0449 \\
(.2421) \\
\end{array}$ & $\begin{array}{r}.0786 \\
(.2723) \\
\end{array}$ \\
\hline DISASTER & $\begin{array}{c}5.4858 \\
(1.8217) \\
\end{array}$ & $\begin{array}{r}5.3370 \\
(1.8585) \\
\end{array}$ & $\begin{array}{r}5.7050 \\
(1.9059) \\
\end{array}$ & $\begin{array}{c}5.8366 \\
(1.9896) \\
\end{array}$ \\
\hline $\begin{array}{l}\text { Fast Incurred } \\
\text { Loss Growth } \\
\end{array}$ & $\begin{array}{r}.4681 \\
(.4279) \\
\end{array}$ & & & \\
\hline $\begin{array}{c}\text { Real Estate to } \\
\text { Total Assets }\end{array}$ & & $\begin{array}{r}.4195 \\
(.3784) \\
\end{array}$ & $\begin{array}{r}.3989 \\
(.3778) \\
\end{array}$ & $\begin{array}{r}.4046 \\
(.3947) \\
\end{array}$ \\
\hline $\begin{array}{c}\text { Liq. Assets to } \\
\text { Liabilities }\end{array}$ & & $\begin{array}{r}-.0494 \\
(.0267) \\
\end{array}$ & $\begin{array}{l}-.0448 \\
(.0217) \\
\end{array}$ & $\begin{array}{c}-.0491 \\
(.0258) \\
\end{array}$ \\
\hline asset size 2 & $\begin{array}{r}-.9813 \\
(.5521) \\
\end{array}$ & $\begin{array}{r}-.9371 \\
(.5409) \\
\end{array}$ & $\begin{array}{r}-.8126 \\
(.4510) \\
\end{array}$ & $\begin{array}{r}-.9477 \\
(.5243) \\
\end{array}$ \\
\hline asset size 3 & $\begin{array}{r}-1.4274 \\
(.5987) \\
\end{array}$ & $\begin{array}{r}-1.3610 \\
(.5817) \\
\end{array}$ & $\begin{array}{r}-1.2596 \\
(.4867) \\
\end{array}$ & $\begin{array}{r}-1.3677 \\
(.5649) \\
\end{array}$ \\
\hline asset size 4 & $\begin{array}{c}-1.4496 \\
(.6853) \\
\end{array}$ & $\begin{array}{r}-1.6406 \\
(.7931) \\
\end{array}$ & $\begin{array}{c}-1.4470 \\
(.6469) \\
\end{array}$ & $\begin{array}{c}-1.5979 \\
(.7631) \\
\end{array}$ \\
\hline
\end{tabular}


Table 12

Mean percentage change in variable between one and two years prior to insolvency $(n=75)$

\begin{tabular}{|l|l|}
\hline Total Assets & $-1.28 \%$ \\
\hline Total Liabilities & $14.48 \%$ \\
\hline Loss Reserves & $18.65 \%$ \\
\hline Losses Incurred During Year & $26.03 \%$ \\
\hline
\end{tabular}

